This item was submitted to Loughborough's Research Repository by the author.

Items in Figshare are protected by copyright, with all rights reserved, unless otherwise indicated.

\title{
Service design PhD education as springboard for social innovations: facilitators and challenges
}

PLEASE CITE THE PUBLISHED VERSION

http://dx.doi.org/10.1080/17547075.2015.1094385

PUBLISHER

(C) Taylor and Francis

\section{VERSION}

AM (Accepted Manuscript)

\section{PUBLISHER STATEMENT}

This work is made available according to the conditions of the Creative Commons Attribution-NonCommercialNoDerivatives 4.0 International (CC BY-NC-ND 4.0) licence. Full details of this licence are available at: https://creativecommons.org/licenses/by-nc-nd/4.0/

\section{LICENCE}

CC BY-NC-ND 4.0

\section{REPOSITORY RECORD}

Lo, Kathy Pui Ying. 2019. "Service Design Phd Education as Springboard for Social Innovations: Facilitators and Challenges”. figshare. https://hdl.handle.net/2134/18493. 


\section{Service Design PhD Education as Springboard for Social Innovations:}

\section{Facilitators and Challenges}

\section{Dr. Kathy Pui Ying Lo}

Academic Lead, Service Design Mini Centre for Doctoral Training,

Loughborough University, UK

K.P.Y.Lo@lboro.ac.uk

\section{Abstract:}

Service design PhD education can act as a springboard for social innovations. This paper proposes five educational emphases that facilitate this goal and discusses their challenges. The PhD education journey starts with a vision focused on social sustainability. The relational dimension in design is explored as critical knowledge that informs the PhD research. Collaborations with communities or organizations need to be incorporated in the research methods. Ideally, research outcomes can involve proposing a service system or service improvements supported by hybrid touchpoints, and the potential for social impact should be part of the PhD research's contributions. This paper contributes to the discussion of design education and social innovation by explaining social driving forces for this educational approach, the five educational emphases, their relationship to elements of $\mathrm{PhD}$ research, their challenges, and current $\mathrm{PhD}$ research topics.

\section{Keywords:}

Service Design, Social Innovation, PhD Education, Relational Messages in Design, Hybrid Touchpoint 


\section{Introduction: Contexts of service design in social innovations}

Societies around the world are facing complicated challenges, such as cultural clashes, environmental degradation, declining emotional wellbeing, and problematic access to social service and healthcare. These societal challenges call for positive transformations in communities (Burns et al. 2006). Service design is increasingly geared towards transformative aims (Sangiorgi 2011) to improve quality of life, with service designers striving to achieve positive transformations. Service design strategies and methods are increasingly employed by both governments and organizations to generate social innovations that help solve societal problems (Holmlid 2009) (Kimbell 2009) (Design Commission 2013) (UK Design Council et al. 2013).

Social innovations often involve the design of holistic service systems - including elements such as service interactions, service procedures, tangible evidence of service, and online service platforms. In response to rising societal challenges and the increasingly crucial role service designers play in tackling these challenges to bring about positive transformations, this paper proposes that service design $\mathrm{PhD}$ education can adapt five educational emphases to foster social innovations.

\section{Five educational emphases}

Figure 1 shows the relationship between the five educational emphases and some elements of $\mathrm{PhD}$ research, including research questions, critical knowledge, methods, outcomes and contributions. How each educational emphasis facilitates social innovation and particular challenges are explained below. This model is purposefully broad so it is applicable across different $\mathrm{PhD}$ research topics under the umbrella theme of service design for social innovation. 


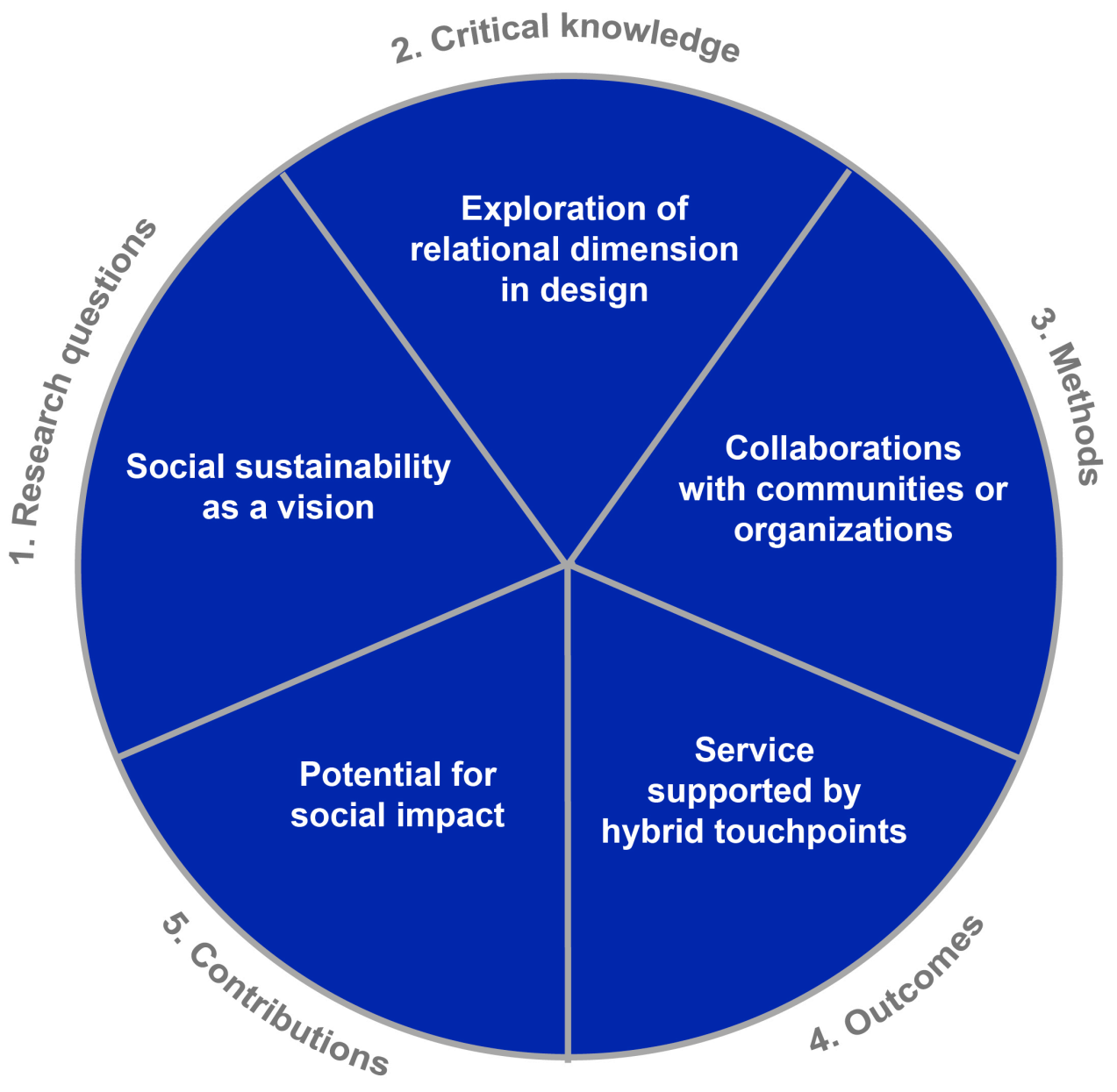

Figure 1 Five educational emphases that facilitate social innovations in service design $\mathrm{PhD}$ education (Original work by Kathy Pui Ying Lo)

\section{(1) Social sustainability as a vision}

Social sustainability needs to be an empowering vision that propels service design $\mathrm{PhD}$ research related to tackling societal challenges or improving quality of life. As a contrast to environmental and economic sustainability in the three pillars of sustainability (Adams 2006), social sustainability is in need of further development (Manzini 2007) (Littig and Grießler 2005). Social sustainability can be defined as a condition when "the formal and informal processes, systems, structures and relationships actively support the capacity of current and future generations to create healthy and livable communities.

Socially sustainable communities are equitable, diverse, connected and democratic and provide a good 
quality of life." (WACOSS quoted in McKenzie 2004, 18) Service design and social innovation fit well with this broader vision. An anthropological analysis of services shows that service design is often responsive to local social contexts with the aim of human betterment (Blomberg and Darrah 2014). Social innovations harness collaborative creativity in communities to generate and diffuse new and more sustainable ways of living (Manzini 2005).

Social sustainability is an overarching theme that $\mathrm{PhD}$ students can aspire to when they clarify their research at an early stage. They should be encouraged to link their research interests with this broader vision. The challenges are: firstly, getting PhD students to understand the importance of social sustainability, and secondly, helping them identify the linkage between the broader concept of social sustainability and their particular research topics at hand. The linkage can then be actualized through manageable research questions that embody the vision of social sustainability.

\section{(2) Exploration of the relational dimension in design}

Social innovations are "new ideas (products, services and models) that simultaneously meet social needs (more effectively than alternatives) and create new social relationships or collaborations" (Bureau of European Policy Advisers 2011). As such, it is beneficial for PhD students to acquire critical knowledge about the relational dimension of service design. For example, the concept of "relational messages in design" advocates that relational factors need to be considered in service design to harmonize the relationships between service providers and users, as well as among service users (Lo, 2011a, 2011b). In terms of harmonizing the relationships between service providers and users, the model outlines design strategies for conveying positive relational messages in service evidence, including care, importance and trust (Lo 2011a). That means, firstly, actualize the service spirit of care in details by designing service evidence that makes the abstract concept of care tangible. Secondly, customize service features according to the needs and preferences of the target users to show the 
importance of these users. And thirdly, optimize users' interactions with the service system by empathizing with users to avoid miscommunicating messages of distrust.

In terms of harmony between users, the concept of relational messages in design can be applied in the design and study of service that involves multiple types of users, especially for sharing purposes. For example, based on the concept of relational messages in design, Tamada, Lo and Mitchell proposed the Relationship Model for Sharing Service (Tamada, Lo and Mitchell 2015) to examine the relationships between different types of users in a sharing service system, namely "service facilitator", "receive-demand customer" and "give-demand customer". For instance, in the service system of Airbnb, the "service facilitator" is the Airbnb service provider; the "receive-demand customer "is the traveler who books the accommodation; and the "give-demand customer" is the local host sharing the home as accommodation space. Studying the interactions between the three types of users will generate insights that inform designing service for harmony between users.

The concept of relational service (Cipolla and Manzini 2009) is also useful. It states that relational service is designed "to start up, support, and continuously sustain interpersonal encounters between the participants." (Cipolla and Manzini 2009, 50) Cipolla (2007) also highlights the importance of relational qualities in service design, which resonates with social innovations' focus on community relationships. Theories about relational messages in design and relational service can serve as appropriate theoretical foundations to support service design $\mathrm{PhD}$ research related to social innovations. $\mathrm{PhD}$ researchers should be encouraged to explore these theories about the relational dimension in design and build critical knowledge in this aspect.

The main challenge of this exploration is in understanding the structure of invisible power, political and social relations in the development of social innovation. For example, different stakeholders have 
different concerns. In the process of developing social innovation, it is natural for each group of stakeholders to prioritize their own agenda. The process of reconciling different priorities and conflict of interest is complicated. Exploration of the relational dimension involves understanding how design process and outcomes can influence the relationships of the stakeholders and vice versa. And this unavoidably touches on some of the politics mentioned above.

\section{(3) Collaborations with communities or organizations}

Design research has a tradition of involving users and stakeholders. User-centered research methods are often employed to ensure design solutions match users' needs and wants. This is particularly important for service design research since service users are sometimes the co-producers of service (Zeithaml, Parasuraman and Berry 1985) (Cottam and Leadbeater 2004) (Maffei, Mager, and Sangiorgi 2005). The use of participatory service design methods in the research process strengthens the $\mathrm{PhD}$ research's outcomes and contributions. Collaborations with communities of users (whether actual or potential) or organizations should be explored in the research design to increase user involvement and potential impact.

Action research can be a useful methodology in this context. Hult and Lennung (1980) have a succinct definition: "Action research simultaneously assists in practical problem-solving and expands scientific knowledge, as well as enhances the competencies of the respective actors, being performed collaboratively in an immediate situation using data feedback in a cyclical process aiming at an increased understanding of a given social situation, primarily applicable for the understanding of change processes in social systems and undertaken within a mutually acceptable ethical framework." (Hult and Lennung 1980, 247) 
In terms of research methods, in recent $\mathrm{PhD}$ research studies conducted in The Service Design Mini Centre for Doctoral Training at Loughborough University, for example, photo elicitation and cultural probes are suggested as research methods to explore the dynamics of emotional interactions between tourists and local community from the participants' point of view (Tamada, Lo and Mitchell 2015); customer journey mapping is incorporated into semi-structured interviews with business travelers to map out opportunities for encouraging selection of sustainable transport service (Murad, Selby and Ross 2015); the research methods of video elicitation and photo elicitation are piloted to find out triggers that evoke people's pleasant and unpleasant experiences in homes within a local community (CorriganDoyle, Escobar-Tello and Lo 2015); also, stakeholder interviews with NHS staff and healthcare service users are conducted. This will be followed by testing of visualization tools for use in participatory design in healthcare service (Canham, Jun and Selby 2015). It must be clarified that these methods are given as examples to illustrate collaboration with communities and organizations, not as prescriptive methods. Other collaborative methods are also applicable.

In terms of challenge, trust-based partnerships with communities or organizations need time to develop. Given the short research period of a PhD degree, building trust in collaborations can be challenging. Nonetheless, initiation of collaborations through $\mathrm{PhD}$ research can be perceived positively as the trigger for building more long-term research partnerships for future research studies. These collaborations can happen during recruitment of research participants, co-design of service systems, testing of service concepts, or application of proposed service systems.

\section{(4) Service supported by hybrid touchpoints}

As part of the research outcomes, the PhD student should be encouraged to propose a service system or suggest service improvements that utilize hybrid touchpoints to support social innovation. Information communication technologies (ICT), particularly those that make use of peer-to-peer technology and 
social media, can facilitate the reach and uptake of social innovations as well as foster community participation (Kaletka et al. 2012) (Rahman and Smith 2014) (Charalabidis, Loukis and Androutsopoulou 2014).

Instead of looking at online and offline service components as separate entities, it is more helpful to examine a pair of online and offline service components as a "hybrid touchpoint" (Lo 2014) when designing or analysing relational service for social innovation. A hybrid touchpoint is a pair of online and offline service touchpoints that connects service users. The online component often involves the use of peer-to-peer digital media. User interactions usually start online and trigger offline real-life interactions. Both online and offline components support each other in achieving service goals under a relational theme. The framework of hybrid touchpoints for relational service (Lo 2014) outlines the relationships between relational theme, service goals, hybrid touchpoints and enabled interactions. Figure 2 shows the framework.

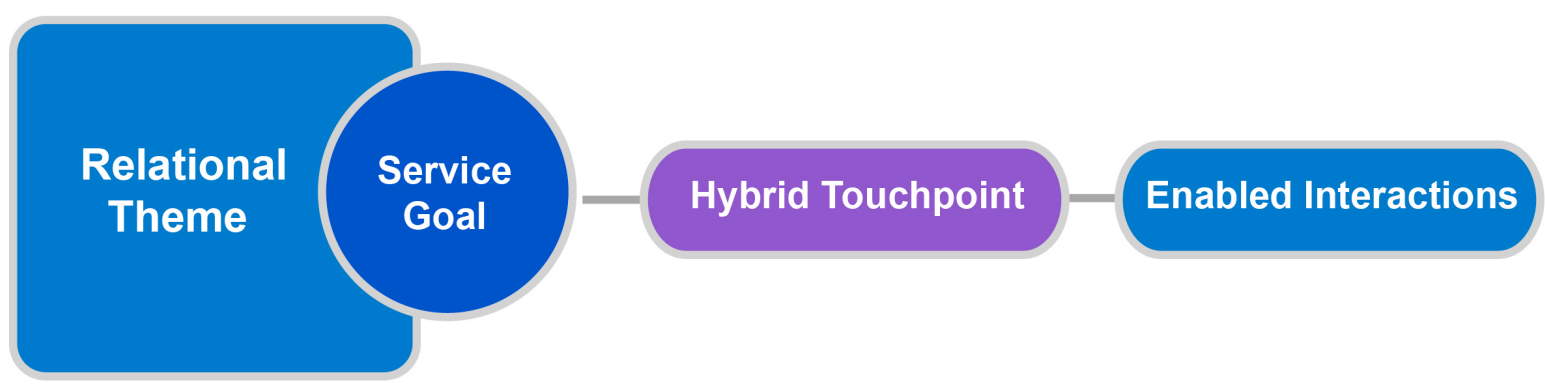

Figure 2 Framework of hybrid touchpoints for relational service (Original work by Kathy Pui Ying Lo, updated version based on Lo 2014)

The framework can be applied as an analytical tool in service design research or a practical tool in service design process. An example is the social innovation called "Crop Club" (previously named "Eat Me!") (Lo 2014). The relational theme of Crop Club is sharing. One of its service goals is to share fruits 
and vegetables in local communities. This is achieved through two pairs of hybrid touchpoints. The first pair is participatory digital maps (online) and visits to growers (offline). Geotagging of sharable fruits on participatory digital maps encourages real-life visits to gardens and allotments in the local community. The second pair of hybrid touchpoint is online network and real-life sharing events for swapping or giveaways. The online community interactions can trigger face-to-face exchange of fruits and vegetables. These hybrid touchpoints enable interactions of give and take, community contribution and gratitude.

One challenge is the temptation to focus on the ICT component rather than the user interactions or relational elements of the service. As design research often has a heavy practice element, the $\mathrm{PhD}$ researcher could be easily carried away in producing the ICT component. The PhD researcher needs to be aware that the use of ICT is a means but not an end. The ultimate aim should be to facilitate user participation by integrating service users' online and real-life interactions. Another challenge is the dynamic nature of communication on open and unmediated online social platforms. The PhD researchers should be mindful of ethical implications when using social media as part of the service components that support social innovation.

\section{(5) Potential for social impact}

Impact, defined as "an effect on, change or benefit to the economy, society, culture, public policy or services, health, the environment or quality of life, beyond academia" (Research Excellence Framework 2012a), is playing an increasingly important role in the evaluation of academic research quality, particularly in countries that allocate funding to higher education institutions based on research performance and award research grants with consideration of potential for impact (Donovan 2011). For example, in the Research Excellence Framework, the recent research assessment of higher education institutions in the U.K., aspects of social impact are defined as civil society, cultural life, economic 
prosperity, education, policy making, public discourse, and public services. The criteria for assessing social impact include: Reach — the extent and/or diversity of the organizations, communities and/or individuals who have benefited from the impact, and significance — the degree to which the impact enriched, influenced, informed or changed the policies, practices, understanding or awareness of organizations, communities or individuals. (Research Excellence Framework 2012b)

Service design $\mathrm{PhD}$ research in the social innovation context might involve proposing solutions to social problems, designing service to improve aspects of community life, and suggesting social practices that enhance cultural harmony etc. As early-career academic researchers, PhD students need to understand and highlight the potential impact of their research. The $\mathrm{PhD}$ researcher should be encouraged to examine their research's potential for impact in terms of reach and significance in aspects of civil society, cultural life, economic prosperity, education, policy-making, public discourse, and public services. Articulation of potential for impact in research contributions not only improves quality of research but also paves the way for further research possibilities beyond graduation.

The main challenge is the difficulty in "measuring" the impact or qualifying it short-term, particularly for an intensive research degree like doctoral study. That said, it is still worthwhile to examine potential impact that is not immediately measurable. An understanding of the potential for impact can lead to a stronger thesis and opportunities for follow-up research that reveals long-term impact.

\section{Current $\mathrm{PhD}$ research topics}

The Service Design Mini Centre for Doctoral Training at Loughborough University is carrying out PhD research projects under the umbrella themes of innovation, travel and wellbeing. Two of the current research projects are particularly relevant to social innovations: (1) Service innovation for improving travelers' experience: This research study uses service design approach to investigate travel services 
enabled by the sharing economy, with the aims of improving emotional experiences and harmonizing relationships between tourists and local communities (Tamada, Lo and Mitchell 2015). (2) Social innovation for happiness and sustainability: This research study explores social innovation in domestic experiences that will challenge existing ideas of "home" and help people achieve sustainable lifestyles, foster social interactions and enhance happiness (Corrigan-Doyle, Escobar-Tello and Lo 2015). The Service Design Mini Centre for Doctoral Training's other PhD research projects include: digital service that utilizes persuasive visualization to foster the uptake of sustainable transport (Murad, Selby and Ross 2015) and information visualization for health service co-design (Canham, Jun and Selby 2015).

\section{Conclusion: Springboard for meaningful contributions}

$\mathrm{PhD}$ education is a phase of critical inquiry that requires research students to generate knowledge and make contributions. This paper has proposed five educational emphases that facilitate social innovations in service design $\mathrm{PhD}$ research. Their challenges are also discussed. $\mathrm{PhD}$ supervisors can choose to apply these emphases selectively based on the relevance to their students' research topics. In response to social and cultural complexities surrounding service design, as well as the constant demand for social innovations, it is beneficial to engender a sense of mission for social sustainability and equip students with necessary knowledge and methods, so that students are empowered to contribute meaningfully in fostering positive transformations through service design and social innovation. The PhD research journey becomes meaningful not only in the sense of contributing to the broader vision of social sustainability, but also through collaborating with communities or organizations, which might lead to service improvements or new service systems that represent a step towards positive social transformations. 


\section{References}

Adams, William M. The Future of Sustainability: Re-thinking Environment and Development in the Twenty-first Century. The World Conservation Union, 2006.

Blomberg, Jeanette, and Chuck Darrah. "Toward an Anthropology of Services." Paper presented at ServDes2014 Service Future - The fourth Service Design and Service Innovation Conference, Lancaster, April 9-11, 2014.

Bureau of European Policy Advisers (BEPA). Empowering People, Driving Change: Social Innovation in the European Union. Luxembourg: Publication Office of the European Union, 2011.

Burns, Colin, Hilary Cottam, Chris Vanstone, and Jennie Winhall. RED Paper 02: Transformation Design. London: Design Council, 2006.

Canham, Nye, Thomas Jun and Andrew Selby. "Visual Tools for Systems Thinking in the Participatory Design of Healthcare Services." Poster presented at DesRes Conference, Loughborough, April 1 2015.

Charalabidis, Yannis, Euripidis Loukis, and Aggeliki Androutsopoulou. "Fostering Social Innovation through Multiple Social Media Combinations." Information Systems Management 31, no. 3 (2014): 225-239.

Cipolla, Carla. Designing for Interpersonal Relational Qualities in Services: A Model for Service Design Theory and Practice. Milan: Politecnico di Milano University, 2007. 
Cipolla, Carla, and Ezio Manzini. "Relational Services." Knowledge, Technology \& Policy 22, no. 1 (2009): 45-50.

Corrigan-Doyle, Emily, Carolina Escobar-Tello, and Kathy Pui Ying Lo. "How Can Service Design \& Art Therapy Create Happy Sustainable Homes?" Poster presented at DesRes Conference, Loughborough, April 12015.

Cottam, Hilary, and Charles Leadbeater. RED Paper 01 Health: Co-creating Services. London: Design Council, 2004.

Design Commission. Restarting Britain 2. London: Design Commission, 2013.

Donovan, Claire. "State of the Art in Assessing Research Impact: Introduction to a Special Issue." Research Evaluation 20, no. 3 (2011): 175-179.

Holmlid, Stefan. "Participative, Co-operative, Emancipatory: From Participatory Design to Service Design." Paper presented at First Nordic Conference on Service Design and Service Innovation, Oslo, November 24-26, 2009.

Hult, Margareta, and Sven-Ake Lennung. "Towards a Definition of Action Research: A Note and Bibliography." Journal of Management Studies 17, no. 2 (1980): 241-250.

Kaletka, Christoph, Karolin Eva Kappler, Bastian Pelka, and Richard Ruiz De Querol, R. R. "Challenges at the Intersection of Social Media and Social Innovation. In Challenge Social Innovation: 
Potentials for Business, Social Entrepreneurship, Welfare and Civil Society, edited by HansWerner Franz, Josef Hochgerner and Jugen Howaldt, 277-292. Berlin-Heidelberg: Springer, 2012.

Kimbell, Lucy. "The Turn to Service Design." In Design and Creativity: Policy, Management and Practice, edited by Guy Julier, and Liz Moor, 157-173. Oxford: Berg, 2009.

Lo, Kathy Pui Ying. "Designing Service Evidence for Positive Relational Messages." International Journal of Design 5, no. 2 (2011a): 5-13.

Lo, Kathy Pui Ying. "Relational Messages in Product Design." Paper presented at DESIRE' 11: International Conference on Creativity and Innovation in Design, Eindhoven, October 19-21, $2011 b$.

Lo, Kathy Pui Ying. "Hybrid Touchpoints for Relational Service in Social Innovation: A Case Study of Eat Me!" Paper presented at NordDesign 2014 International Conference organized by Aalto University and Design Society, Helsinki, August 27-29, 2014.

Littig, Beate, and Erich Grießler. "Social Sustainability: A Catchword between Political Pragmatism and Social Theory." International Journal of Sustainable Development 8, no. 1/2 (2005): 65-79.

Maffei, Stefano, Birgit Mager, and Daniela Sangiorgi. "Innovation through service design. From research and theory to a network of practice. A user's driven perspective." Paper presented at Joining Forces Conference, University of Art and Design Helsinki, September 22-24, 2005. 
Manzini, Ezio. "Enabling Solutions for Creative Communities: Social Innovation and Design for Sustainability." Designmatters 10 (2005): 45-52.

Manzini, Ezio. “Design Research for Sustainable Social Innovation”, In Design Research Now, edited by R. Michel, 233-250. Basel, Switzerland; Boston: Birkhäuser, 2007.

McKenzie, Stephen. Social Sustainability: Towards Some Definitions. Magill, Australia: Hawke Research Institute, 2004.

Murad, Syed, Andrew Selby and Tracy Ross. "Evaluate Visualisation Techniques to Encourage Corporate Travellers to Choose Sustainable Transport." Poster presented at DesRes Conference, Loughborough, April 12015.

Rahman, Reem, and Leland Smith. Social Innovation Mapping: Social Entrepreneurs Changing Lives through ICT. Arlington: Ashoka, 2014.

Research Excellence Framework (REF). 2012a. "Assessment Framework and Guidance on Submissions." Research Excellence Framework Website. Accessed May 17, 2014. http://www.ref.ac.uk/media/ref/content/pub/assessmentframeworkandguidanceonsubmissions/GOS \%20including\%20addendum.pdf

Research Excellence Framework (REF). 2012b. "Panel Criteria and Working Methods - Part 2D: Main Panel D Criteria." Research Excellence Framework Website. Accessed January 31, 2015. http://www.ref.ac.uk/media/ref/content/pub/panelcriteriaandworkingmethods/01_12_2D.pdf 
Sangiorgi, Daniela. "Transformative Services and Transformation Design." International Journal of Design 5, no. 2 (2011): 29-40.

Tamada, Momoko, Kathy Pui Ying Lo, and Val Mitchell. "Service Design for the Development of Emotional Connection between Host Community and Travellers." Poster presented at DesRes Conference, Loughborough, April 12015.

UK Design Council, Danish Design Centre, Design Wales, and Aalto University. Design for Public Good. London: UK Design Council, 2013.

Zeithaml, Valarie, A. Parasuraman, and Leonard L. Berry. "Problems and Strategies in Services Marketing." Journal of Marketing 49, no. 2 (1985): 33-46. 